\title{
Soil as a Basis to Create Enabling Conditions for Transitions Towards Sustainable Land Management as a Key to Achieve the SDGs by 2030
}

\author{
Saskia Visser ${ }^{1}$, Saskia Keesstra ${ }^{2,3} * \mathbb{1}$, Gilbert Maas ${ }^{2}$, Margot de Cleen ${ }^{4}$ and Co Molenaar ${ }^{4}$ \\ 1 Wageningen Corporate Strategy and Accounts, Wageningen University \& Research, Droevendaalsesteeg 1, \\ 6708PB Wageningen, The Netherlands; saskia.visser@wur.nl \\ 2 Wageningen Environmental Research, Wageningen University \& Research, Droevendaalsesteeg 3, \\ 6708PB Wageningen, The Netherlands; gilbert.maas@wur.nl \\ 3 Civil, Surveying and Environmental Engineering, The University of Newcastle, Callaghan 2308, Australia \\ 4 Rijkswaterstaat, Griffioenlaan 2, 3526LA Utrecht, The Netherlands; margot.de.cleen@rws.nl (M.d.C.); \\ co.molenaar@rws.nl (C.M.) \\ * Correspondence: saskia.keesstra@wur.nl
}

Received: 11 November 2019; Accepted: 25 November 2019; Published: 29 November 2019

\begin{abstract}
The Sustainable Development Goals (SDGs) can be grouped into three domains, the environmental domain, the social domain and the economic domain. These different layers influence each other; hence sustainable progress in the economic layer cannot be achieved without good progress in the two other layers. To achieve the SDGs, transitions in the current system are needed and actions should be taken that support transitions and contribute to short term needs and long term (global) goals. Therefore, it is necessary to have knowledge of transitions and understand the different phases of transition. In this paper we discuss the key role of the soil-water system in these transitions and the achievement of the SDGs by 2030. The increasing pressure on land calls for multi-use of land and for the restoration of degraded land. Healthy soils and healthy land are the basic conditions for the successful implementation and realization of the SDGs. To enable a sustainable management of the soil and water system a transition approach is a prerequisite. In the X-curve used to describe transitions, soil and land stakeholders are given a framework, which provides perspective for action, specifically for science and governance stakeholders in each phase of the transition. This framework can provide the required intensive guidance to (1) analyze the impact of provided incentives, (2) identify new reference points in the transition and (3) stimulate transition catalysts, and (iv) innovate by testing cutting edge policy instruments in close cooperation with society. The key to make the necessary transitions and realize the SDGs by 2030 lies in the intensive guidance to combining initiatives, steering knowledge flows and continuously assessing the stage of the transition, in order to plan specific steps needed to progress in the transition framework. Both scientist and policy makers have an important role in this guidance.
\end{abstract}

Keywords: sustainable development goals; land degradation neutrality; transitions; sustainable land management; new business models; transition science

\section{Introduction}

In 2015 the United Nations have adopted the Sustainable Development Goals (SDGs) to address the global challenges of our time [1]. The interrelationships between the different SDGs are illustrated in a paper by the Stockholm Resilience Centre [2]. They group the SDGs into three domains, the environmental domain, the social domain and the economic domain. These different layers influence each other; hence sustainable progress in the economic layer cannot be achieved without good progress 
in the two other layers and vice versa. The key question in realizing the SDGs before 2030 is: "How can we create a balance between environmental, economic and social interests over a range of interconnected scales?". Many challenges the world faces, such as climate change, food security, water resources and sustainable energy are hindered by poor economic conditions or social structures.

One of the challenges, that lies underneath all these global goals, is the challenge to reverse land degradation. Land degradation was defined by the UNCCD as [3]:

"The reduction or loss, in arid, semi-arid and dry sub-humid areas, of the biological or economic productivity and complexity of rainfed cropland, irrigated cropland, or rangeland, pasture, forest and woodlands resulting from land uses or from a process or combination of processes, including processes arising from human activities and habitation patterns, such as: (1) soil erosion caused by wind and/or water; (2) deterioration of the physical, chemical and biological or economic properties of soil; and (3) long-term loss of natural vegetation".

Land degradation forms a threat to the capacity of land to provide ecosystem services that are needed to reach the SDGs. Land Degradation-Neutrality (LDN) is imbedded in Sustainable Development Goal (SDG) target 15.3. LDN is described as "a state whereby the amount and quality of land resources necessary to support ecosystem functions and services and enhance food security remain stable or increase within specified temporal and spatial scales and ecosystems" [4].

In an attempt to work towards the SDGs many initiatives, at a rage of scales have started over the last few years. Some examples are: '4 per 1000 initiative' [5], 'the decade of Biodiversity' (https://www.cbd.int), 'circular society' (https://circularsociety.com), '100 million trees by 2017' (https: //sustainabledevelopment.un.org/partnership/?p=132), 'Green initiative.eu' and 'Resource efficiency, using less, living better' [6]. All these initiatives aim to work towards a more sustainable planet, however, when all these initiatives would be executed adjacent to each other, we would need 3 or 4 planets Earth to have enough land to support all initiatives, despite their individual sustainable ambitions. In addition, some of the initiatives are not compatible with each other, as they have competing claims on the land. Therefore, to find the right balance, on only one Earth, we need smart and robust land use and management plans and have to make political and policy decisions based on priorities and choices, realising that not always all wishes can be granted. The basis for these plans is a resilient and healthy soil-water system, which provides the full set of ecosystem services [7].

These ecosystem services are required to also sustainably reach the economical and societal SDGs. As land degradation rehabilitation takes 10 to 20 years, the basis for the political and policy decisions should be an integral long-term vision and strategy. Hence our hypothesis is that a robust land-use and land-management plan supported by a sustainably managed soil-water system is needed to provide the basis for reaching the SDGs. Using this hypothesis, society can develop interlinked agendas for the SDGs throughout the three different layers in Figure 1, facilitating the required economic and societal transition and necessary political and policy priority and decision making.

At this moment the dominating domain is the economy. To achieve the SDGs taking into account all domains, innovations are not enough. The growing world population, the growing need for resources, the pressure on the environment, the growing gap between haves and have nots and climate change ask for disruptive changes in the current world regime and economy. Transitions in the current system are needed and actions should be taken that support transitions and contribute to short term needs and long term (global) goals. Therefore, it is necessary to have knowledge of transitions and understand the different phases of transition. In this paper we show how knowledge of transitions helps to develop instruments for short and long-term actions in land restauration, sustainable land use and management and land and soil policy.

Transition science can be described as a research field that studies the interplay between humans and the systems around them in which they operate. The key difference compared to business as usual, is to look for system and policy innovation. This is essential as business as usual, or even innovations as usual, are insufficient to resolve the wicked problems mankind is facing [8]. 


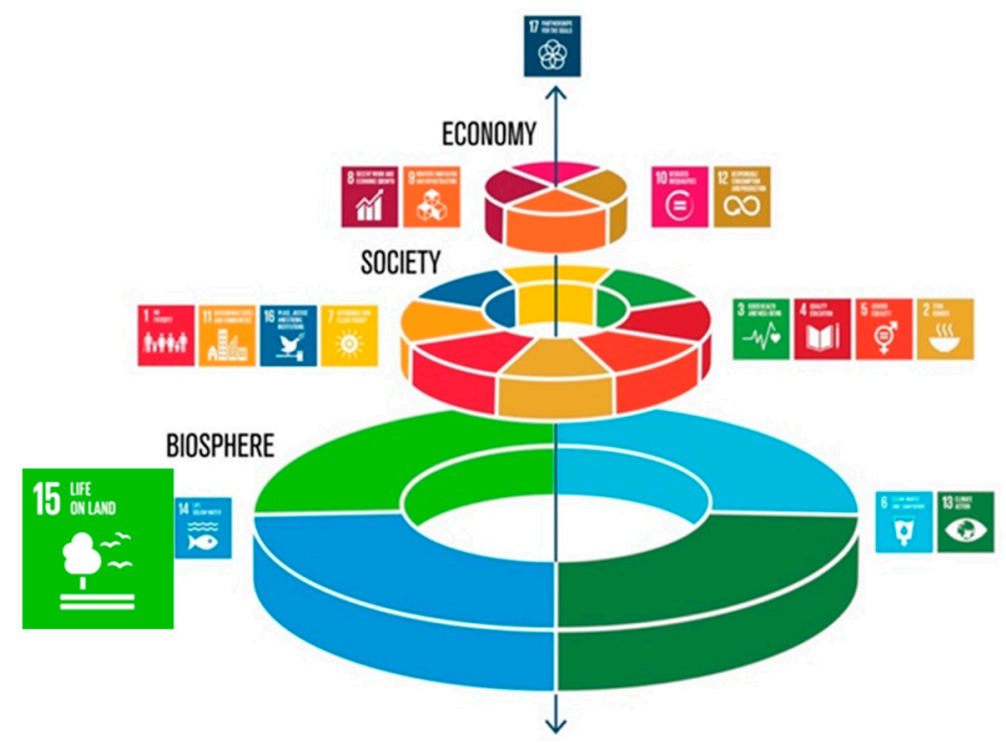

Figure 1. Relation of different domains within the SDGs, Biosphere, Society and Economy (adapted after the original Figure of [2]. This model shows that economies and societies are embedded parts of the biosphere. The current sectorial approach where social, economic, and ecological development are seen as separate parts has to transition into a paradigm in which economy serves society while not damaging the biosphere.

An example of a transition is the guided increase of scale of the Dutch agriculture after World War II with as main driving force the desire for food security and low food prices. Characteristics were rationalization of production, mechanization and specialization in the sector combined with structural changes and economic incentives supported by all stakeholders involved. Structural changes induced and supported by the government were product subsidies, education and research and land consolidation to allow a more profitable use of land. The Dutch banking system supported the structural changes by granting loans to farmers to invest in the innovation and extension of their farms. So, there was cooperation between organizations representing the farming community. Result was that production increased enormously and The Netherlands became worldwide second largest agricultural exporting country.

The increase in scale and rationalization has led to side effects: loss of biodiversity by large monocultures, intensive use of resources, animal diseases, low incomes for farmers, loss of soil fertility and soil compaction. These side effects are such that innovative measures optimizing the current system are not enough, a new structural change towards another form of agriculture are needed, such as circular agriculture. Another world view is part of such a structure breach.

Rotmans [9] described characteristics of a new world view that can help to define actions to facilitate the now required transitions. In this world view, problems are solved in a cooperation model (as opposite to an exploitation model), are business models no longer centered around economic return, but focused on societal return and focused on value creation instead of value extraction. They argue that this new world view can be reached by making use of a new structure in which responsibilities are decentralized and communities will solve problems bottom up through networks. This structure is quite different from the "current" structure where problems are solved top down in silos, following a hierarchic, centralized structure. In a transition process no guidelines are available to facilitate the transition, but tailor-made application of a set of solutions are the key to the successful transition [10,11]. Loorbach et al., [12] argued that for sustainable transitions, societal changes are needed. They describe three different types of approaches in transitions science that nicely align with the three levels of interference in Figure 1: Socio-technical (Economy in Figure 1), socio-institutional (Society in Figure 1), and socio-ecological (Biosphere in Figure 1). In the socio-technical approach the emphasis lies on technological innovation; in socio-institutional on political and institutional 
change, and in socio-ecological on ecological thresholds and extraction of fossil resources to renewable resources within closed cycles through adaptive management.

Hajer [13] analyzed the question "how can governments exploit the potential of the new energetic society on the road to sustainability" and concluded that the path to a circular economy requires intensive guidance. Though the magnitude of the sustainability issue is such that policy only has a chance of success if it results in an active quest for new operational options at all levels and amongst governments, individuals and businesses. Braat et al., [7] identified governance challenges to reach a circular economy and concluded that a need exits to create concerted action, taking into account stakeholder involvement and fairness on all levels for fair and sustainable decision-making, investment, action and finally outcomes.

Transitions are anarchistic processes which cannot be planned. Policy makers who want to guide and steer transitions or NGO's and scientists who want to influence or change the dominant system from the current industrial phase, with its heavy use of resources, to a more sustainable phase with an awareness of ecological limits have to be aware of this. Hence, they have to find ways such as protect, stimulate or empower certain niches of change, put pressure on the dominant system, take advantage of and use macro developments enhancing awareness, attention and visibility but also contribute to building the new system and breaking off the dominant system. Hence governance and science have an important role to play in the current transitions. They can provide the required intensive guidance, whilst at the same time analyze the impact of policy, identify new reference points in the transition, identify transition catalysts, innovate by testing cutting edge policy instruments in close cooperation with society. As such the transition process will allow for social learning, empowerment and social capital which are prerequisite to a transition to sustainability.

The main focus of this paper lies on science and policy needs in a transformation from a system dominated by the economic system towards a system where sustainable land management is a basis to realize the SDGs. Therefore, the objectives of this paper are: (1) Describe enabling conditions that can facilitate societal transitions to sustainability with a healthy soil-water system as a basis (2) showcase sustainable business cases of integrated land management approaches, (3) provide a transition framework that helps to evaluate the current state of the transition in The Netherlands (4) and identify the role of knowledge management to facilitate the transition to reach the SDGs with soil as a basis (environmental, economic and social).

\section{Enabling Conditions Needed for Transitions}

To be able to use soil and land management as a basis for transition we need to consider the three domains of the SDGs, like is best illustrated by the Figure of the Stockholm resilience center (Figure 1). The three domains all need to be addressed in the transition agendas. In this section we address the enabling conditions of each domain which together give form to sustainability: the environment, the economy and the society.

\subsection{Biosphere}

The basis for the development of a sustainable situation is to ensure that the biophysical environment is used within its system boundaries and its natural resources are not used beyond the tipping point of the environmental system [14]. In the new world view the system and its natural functions are leading in land use changes and societal challenges, as opposed to being adapted because of economic incentives. A recent development in sustainable land management strategies is to include natured base solutions. To implement nature based solutions we need knowledge on (1) the system to which we intend to apply the solutions [15], (2) understand the system dynamics; e.g., the connectivity of water and sediment [16] and (3) find nature based solutions to manage the system within its boundaries whilst making use of its dynamics [16,17].

As land and soil are the focus points of this paper it is important to consider the on-site soil functions as a basic knowledge of the system. Even though there are many variables; soils and the 
knowledge of how a soil functions under different management treatments, is key to reach sustainability. The soil functions as described by the EU [18] have a direct link to most of the SDGs [19]. All seven soil functions [20] can be impacted by soil threats that somehow change the usability of the soil and can provoke degradation. On the other hand, a well-maintained soil can contribute to realising the SDGs. Examples are: soils can store carbon to mitigate climate change (SDG 13) [6]; a healthy soil is in balance with the life on land (SDG15), can produce healthy food (SDG $2 \& 12$ ) and clean water (SDG 14). The state of the soil functions can be grouped into one term: Soil health, which can be assessed by a variety of indicators [21] and provides a good indication of the soil functions for specific land uses [22]. However, there is a strong need for a robust basis under all these indicators to be able to compare their outcomes and relate management strategies to the outcomes [23].

Apart from understanding the system components, it is important to understand the system dynamics. Specifically, knowledge of how water and water transported substances such as sediment, solutes and associated substances like pollutants attached to soil particles, are transported through a soil and through the landscape provides the starting point for the application of natural based solutions. The science to describe these processes has been defined as connectivity $[24,25]$. The determining factors for these transport paths and volumes of transported material can be grouped in two categories: 1) The characteristics of the landscape and 2) the drivers in the landscape. The landscape characteristics fall apart in climatic setting, relief, soil and geology, vegetation, and long-term land management strategies. The drivers are factors like rainfall characteristics, fire regime, weather conditions, short-term land management actions (e.g., ploughing) and land use change decisions. Together the landscape characteristics and drivers determine the fate of the transportable substances, and finally, over a longer period the landscape itself, through co-evolution of the landscape and the fluxes in it. This knowledge is vital as they determine the impact a chosen land or water management strategy will have on the fluxes in the system.

Knowing the system and its dynamics, in agricultural settings Keesstra et al., [17] described the use of nature-based solutions to reach sustainable system stewardship. Soil-scale solutions, such as the use of cover crops or straw mulching brings many benefits. Landscape solutions are all based in promoting the dis-connection of the water and sediment transfers through the landscape. Vegetative buffer strips, hedge rows and riparian vegetation are examples of suitable measures. Furthermore, nature-based solutions can be used in urban settings as well. Here nature-based approaches can be applied on man-made infrastructure such that the infrastructure is adapted to and may even enhance the natural processes, instead of adjusting the environment to the demands of men [16]. For example, wadies to store and clean rainwater instead of sewers.

Hampering conditions for adoption of nature-based approaches in agricultural land management are often impacted by issues related to incentives of farmers that lie in the two other layers in Figure 1. Subsidies that provoke land degradation, such as implantation of drip irrigation in dryland farming areas; or no tillage practices that increase the use of herbicides. Furthermore, due to the system dynamics, the sustainable management activities of an individual land user may have a minimal impact, whereas joint implementation of measures throughout the system will have a much larger impact, and may also be more cost efficient.

Hence, it is essential that land managers either have access to landscape specific knowledge and the capacity or instruments to analyze and predict the trade-off-effects of a chosen land management intervention. Therefore, there is a need for guidance and knowledge transfer on the level of practitioners to provoke joint implementation of sustainable land management practices. The role of policies and awareness raising in this process is described in the following section.

\subsection{Society}

In this section we will have a look at the enabling conditions needed in the society domain. We specifically focus on perception and awareness of society of land degradation processes and sustainable land management. 


\subsubsection{Land Degradation Perception}

Land degradation is a subjective concept. Soil sealing for housing can be considered as value creation by the building sector and policy makers responsible for housing but as degradation by farmers or nature conservationists. In different parts of Europe land degradation is also perceived very differently and there are differences between rural and urban environments. In Mediterranean countries rural stakeholders are mostly aware of the risk of soil erosion while they can see vast volumes of soil displaced after one thunderstorm (Figure 2). The Mediterranean landscape is vulnerable due to semi-arid vegetation and high intensity rainfall in combination with steep relief landscapes. Furthermore, the high evaporation access combined with irrigation practices induce the risk of alkalization and salinization of the soils. However, social pressure to keep your soil clean of weeds is large, this limits the adoption of nature-based management solutions such as organic farming and the use of straw as a mulch [26,27]. In the northern Europe, a different problem seems to prevent progress towards the realization of land degradation neutrality, (SDG15.3). As the common degradation processes, like diffuse pollution, compaction, submerging soils and compaction are less visible, the evidence of Land degradation only now starts to become more and more visible Public awareness of the pressure on the land and soils is limited as most people live and consume in cities. Furthermore, these degradation processes are progressive, and one can bypass direct negative impacts of e.g., soil productivity by application of fertilizers and irrigation. Consequently, no short-term economic incentives are yet present for long term sustainable soil management contributing to reversing land degradation.

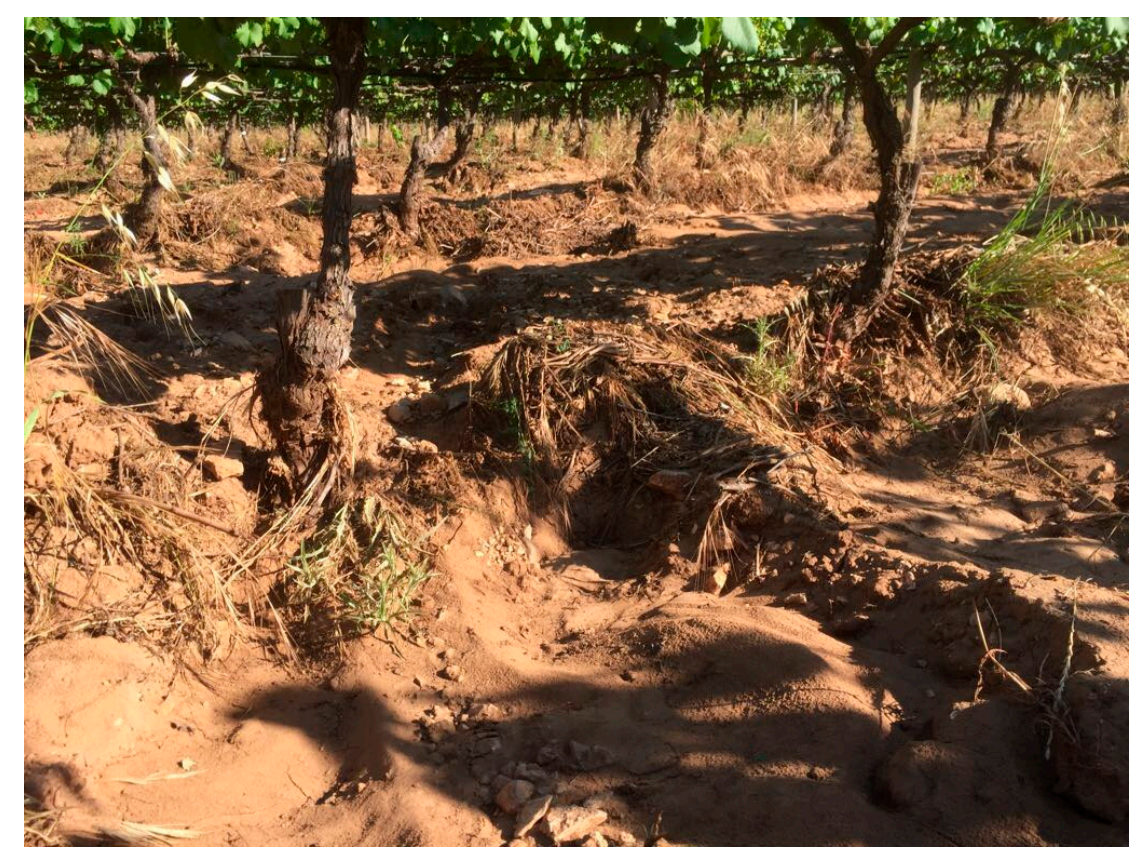

Figure 2. Severe water erosion in a vineyard in Eastern Spain after a single intense summer rainstorm.

Urbanization and industrialization are drivers for soil sealing which cause a significant change in the capacity of the soil to provide its ecosystems services [28] (Figure 3). Some soil functions like the production of food and fibre is especially critical in areas with relief, where the usually most fertile soils in the valleys are, or are under threat to be sealed, and the most valuable soils from an agronomic point of view are lost for production [29]. In addition, the soil loses its capacity to infiltrate rainwater and therefore causes increased runoff, which can contribute to flooding and droughts [25]. In many cases, these land use transition decisions are made without taking the consequences of these changes on other functions of the landscape, into account. These consequences can be costly. As an example, 
soil sealing contributed greatly to a flood in the city of Arnhem, The Netherlands in 2014 [30], the costs related to this flooding event mounted up to several million euros.

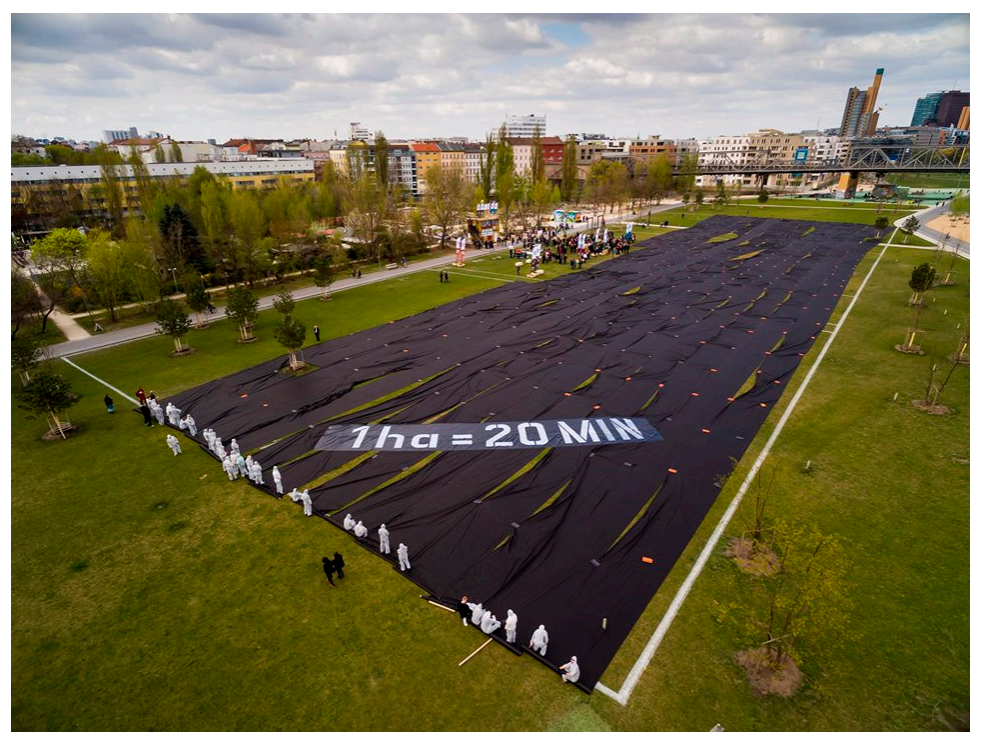

Figure 3. Soil Sealing, a picture made during a demonstration of the soil sealing rate in Europe.

\subsubsection{Land Degradation Awareness}

Since the start of the Year of Soils in 2015 more and more attention is being paid to healthy soils as a prerequisite for sustainable production. Over the last years many initiatives to promote sustainable land management have started [31]. Even though some initiatives have truly transformative capacity, in general these individual initiatives lack coherence, communication of successes and failures and upscaling capacity. Termeer and De Wulf [32] developed a small wins theory. Small wins are drastic innovative approaches that answer the global challenges at local level. They developed a framework that facilitates the deepening, broadening and spreading of the success of the small wins. Following the line of thought of Termeer and de Wulf [32], in order to realize the transition to sustainability, with a robust land use and land management plan supported a healthy soil-water system, stability of policy in terms of sticking to ambition, continuing to emphasize urgency and promoting progress, is needed. The involvement of a large group of public and private stakeholders, that are deeply involved in the transition, can make an important contribution to the robustness and thus the stability of the ambition. The connection with other social issues, such as linking to climate mitigation to the energy transition, and the further integration of social and technical innovations will further strengthen the robustness of the ambition. In The Netherlands this is implemented through the development of the Soil strategy that underpins the transition to circular agriculture.

Regarding soil sealing it is necessary that the awareness of the process and its consequences will trickle through into the minds of the public and policy makers when deciding about land use and the specific functions of an area in relation to the surrounding functions. The European Commission has provided guidelines on the best practices to limit, mitigate or compensate for Soil sealing [5], and in The Netherlands all cities need to execute a climate "stress test" in order to identify potential risks (https://ruimtelijkeadaptatie.nl/stresstest/handreiking/).

\subsection{Economic Sustainability: Sustainable Business Development}

SDGs and consequently sustainable soil management, are not only necessary for our survival, but are an economic opportunity as well. Sustainable business does not need to be less profitable, though awareness is needed on the multiple benefits that can be derived by successfully implementing the SDGs. Product prices are not extracted by single parties, but depended on values created for stakeholders and communities, environmental losses are minimized instead of transferred to the 
community. Herein, sustainable entrepreneurs are key actors; they develop innovations, create markets, and put pressure on incumbents. However, investigations on the role entrepreneurs can play in sustainable transitions, shows that in general entrepreneurs are constrained by ineffective policy, resistant users, as well as novel alignment issues within the supply chain [33]. Take for instance the way soils, organic waste, sewer sludge and sediments mostly end up in landfills, due to the strict regulations for contaminants, while these resources could also be sustainably used as soil or for soil improvement. This requires innovations in the treatment of biomass flows and adaptation of regulations that are incorporated in well-developed circular economic strategies. Thus, they may form a way ahead to reduce the resource footprint of for example a construction company [20]. To achieve sustainability from an economic but also from a resource perspective, one needs to overcome these barriers, which should start as outlined in the introduction with a new world view, for example waste does not exist and landfilling should be avoided, loops should be closed. In the Netherlands a range of initiatives facilitate this transition towards a circular economy. For example, since 2011, Green Deals are being developed (https://www.greendeals.nl/). With this interactive business model, the government wants to give space to innovative, sustainable initiatives from society. Within such a green deal bottlenecks in legislation and regulations are removed creating new markets, providing good information and ensuring optimum partnerships. Through clear mutual agreements, participants can work on concrete results, whereby each party involved has its own responsibility. Since the start in 2011, over 100 of these green deals have established in The Netherlands, each providing tailor made solution towards a sustainable economy.

\subsection{Knowledge Management}

Public awareness is raising although, as with the small wins, in isolation, e.g., in individual countries, regions or cities. In order to create large-scale awareness and access to solutions we propose a knowledge management approach following a theory of Dalkir [34]. For sustainable soil management new knowledge needs to be (1) developed and synthesised, (2) shared and transferred, (3) harmonised, stored and organised and (4) applied in practice. A good example of application of this knowledge framework is presented by Keesstra et al. [35] in the roadmap of EJP SOIL. This roadmap describes the knowledge management process that facilitates knowledge flow between diverse stakeholders in soil management and provides perspectives needed for actions like: translation of scientific papers into usable management information, and translation of policy documents and stakeholder demands into scientific questions; creation of networks and communities of practice to facilitate the knowledge flow, stimulation of knowledge development and exchange (Figure 4).

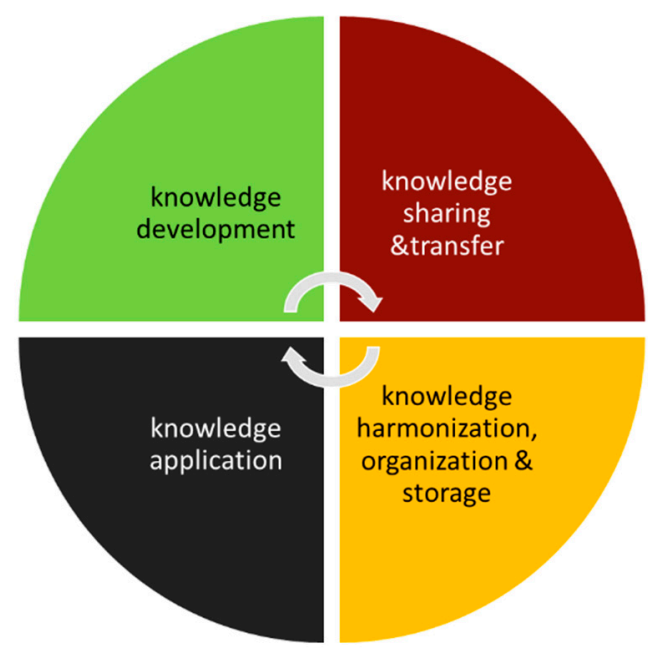

Figure 4. Knowledge framework to facilitate the flow of knowledge (1) development, (2) sharing \& transfer, (3) harmonization, organization \& storage and (4) application. The circularity dictates new needs for knowledge development from each other compartment (adapted from [34,35]). 


\section{Showcase Sustainable Business Cases of Integrated Land Management Approaches}

In this section we will show 3 sustainable business cases of integrated land management approaches as an example to explain how transitions in management strategies support multiple SDGs at the same time. In each of these examples the initiator had an aim that was associated with a different SDG, but in the end multiple SDGs have been served by the implementation of the chosen holistic management approach.

\subsection{Example 1: Organic Farming for Clean Water}

The core issue that started the process in this example, was water quantity and water quality. A water company in The Netherlands wanted to have more and cleaner water. Hence the company needed to increase production of drinking water and to reduce the costs to purify the water. Therefore, they needed the farmers working in the groundwater recharge area to (1) use less water for irrigation, (2) use less fertilizers and pesticides and (3) facilitate groundwater recharge through increased infiltration.

Transfer to organic farming would help accomplish these goals. Organic farming has proven to increase infiltration [36], reduce runoff and erosion [37,38], reduce nutrient loss [39], reduce irrigation need [40] and by principle organic farming does not make use of pesticides and artificial fertilizers. However, in The Netherlands many farmers have difficulties to make the switch to organic farming given the issue of the economic return. In the initial years after changing the farm management to organic farming the soil needs time to recover from decennia of fertilizer and pesticide use, and often initially the production goes down. The organic matter content needs to be restored, the soil life needs to come back; and this takes time [41,42]. In addition, in the first years the products produced on a newly converted farm cannot be sold as organic yet, while the farmer does need to invest time and money. All these drawbacks make that many farmers decide to remain with their conventional way of land management. In the case of the groundwater company in The Netherlands, a start was made on the other side of the production circle (Figure 5). To convince dairy farmers in the region to change to organic farming, the water company paid the dairy company to pay the farmers in the transition period as if the milk they produced was already as certified organic milk. In this way the farmers were able to cope with the transition phase without losing their income.

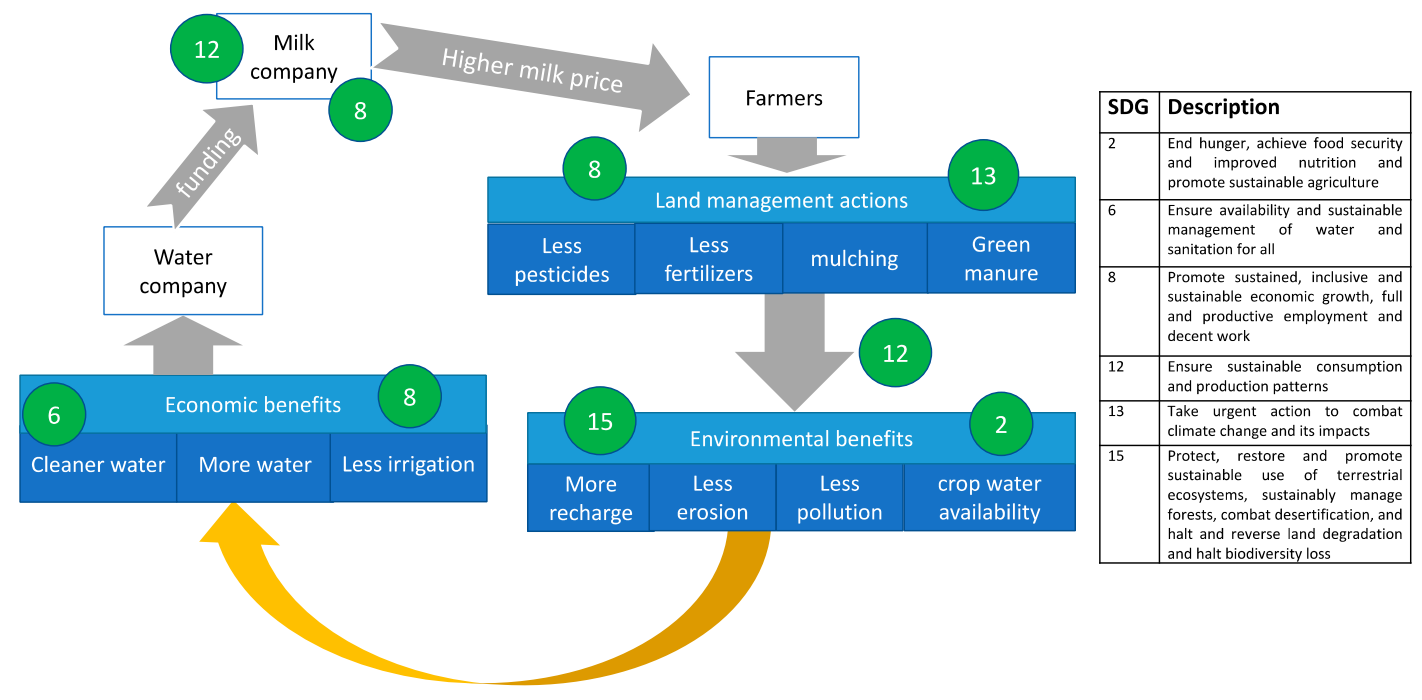

Figure 5. Example of a sustainable robust economy; Organic farming for clean water.

The success story of this approach was that after five years the farmers were producing organic milk and have a healthy economic business, whereas the water company has cleaner and more water, which enhanced their business. In this way, after an initial start-up phase the circle was running by itself, without external economic input, with a sustainable managed environment. 
In this example the circle described that had its initial focus on SDG 6, cleaner water, not only served this SDG, but also several other SDGs (Figure 5). SDG 15, life on land: The soil function and ecosystem services the land provide are highly improved, like carbon sequestration (SDG 13). SDG 12 , sustainable production: The milk and also the water is now produced with much fewer chemical interventions. SDG 8, sustainable economic growth: All partners in this circle benefit from this new way of working, whilst producing organic milk which contributes to SDG 2. This example also shows that soil and land management essential to make this circle effective. The organic management increased the capacity of the soil to deliver its functions, and with that the ecosystem services needed for this transition to happen.

\subsection{Example 2: Nature Based Solutions for Climate Resilient Cities}

In the second example the core issue that started the process was the urgency for municipal governments to take climate change adaptation measures (SDG 13 Climate Action). More and more cities have to cope with flooding and periods of drought and extreme heat due to climate change. Stress tests identify the most important climate change vulnerabilities. The logical reflex is to fix the bottlenecks locally and one by one with technical measures; for example, by increasing the capacity of the sewage systems. Another approach is looking at the natural soil- and water system in and surrounding the city. The position of the city in its natural environment determines the vulnerability to the effects of climate change to a great extent. Many Dutch cities like Amsterdam and Rotterdam are situated below sea level, in low-lying peat areas in the Rhine-Meuse delta. This makes the cities susceptible to flooding as a result of sea level rise and river discharges, as well as to soil subsidence causing damage to houses and infrastructure. Cities on slopes and higher lying sandy areas have to cope with flooding caused by runoff during peak showers and with drought and heat stress in periods of extreme and long-lasting heat. As the environmental position is related to the susceptibility of cities for climate change, characteristics of the natural soil- and water system can be used to increase resilience to climate change. An example of this is the city Ede. Ede is located on the flank of the Veluwe hills, an ice pushed ridge of approximately 100 meters high. Peak showers lead to runoff of the slopes and flooding in the lower parts of the city.

In addition, highly paved areas such as the city centre and business parks need to cope with heat stress, that cause pressure on the liveability and labour productivity during hot summer days. By portraying the integrated soil- and water system below the city, multiple climate adaptive zones could be identified based on specific physical soil characteristics. Identification of these zones constructed the build-up to a climate strategy of rainwater infiltration in the uphill city districts, temporary water conservation in "wadi's" on the slopes and to the creation of supplementary green areas for surface water storage in the lower districts and in business parks (Figure 6). By conserving and infiltrating rainwater instead of draining it, the strategic freshwater reserves in the Veluwe hills are recharged and groundwater sensitive nature is protected against drought (SDG 6 clean water). Temporarily conserved water can be used to provide cooling, by establishing water squares in compact city centres. For storing of water, green retention areas can be established, which contribute to a healthier living environment for employees during their breaks and to enhanced biodiversity and air quality in the city. Hereby, the water squares and green retention areas both contribute to SDG 11, Sustainable cities and communities. 


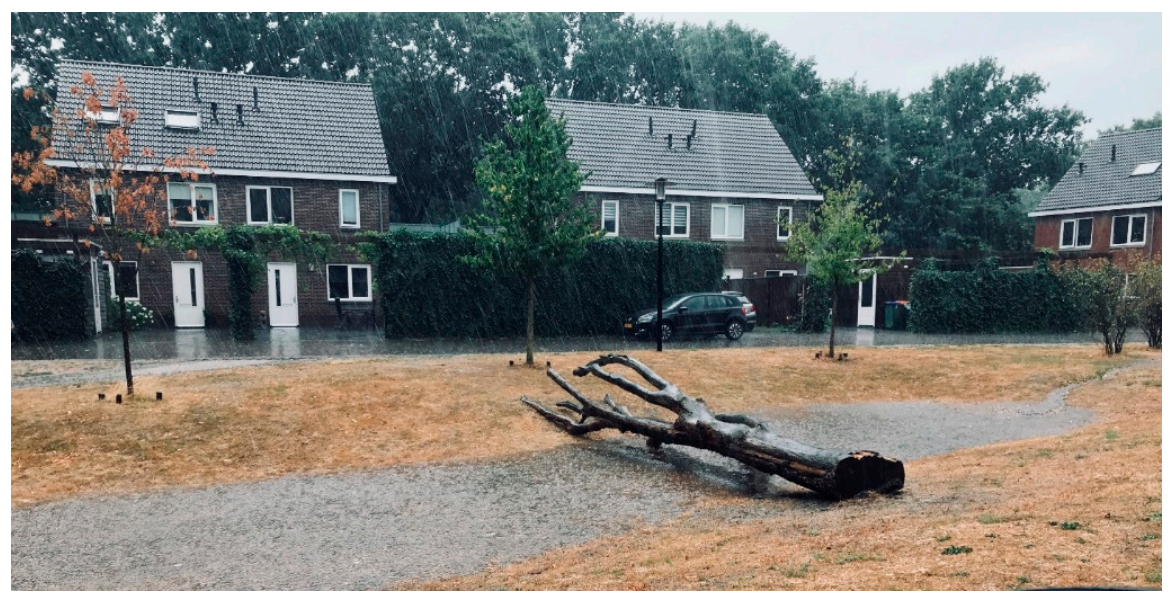

Figure 6. Example of temporary rainwater conservation and infiltration in "wadi's" on slopes in Ede, The Netherlands (picture Koen Claassen).

\subsection{Example 3: Climate Smart Agriculture}

The concept of Climate-Smart Agriculture (CSA) was originally developed by FAO and officially presented at the Conference on Agriculture, Food Security and Climate Change in 2010 in the Hague [43]. Climate-smart agriculture presents an opportunity for advancing the multiple win of sustainable food production (SDG 12), rural development (SDG 8) climate change mitigation and adaptation (SDG 13), and ecosystem resilience (SDG 15). Though originally considered as an approach to combat climate change and ensure food security specifically in developing countries, also in the EU Climate smart agriculture (CSA) solutions can provide an alternative to farmers who are considering ways and strategies to change their farm management by either adopting new technologies or more advanced or innovative management. Though many technologies and solutions for CSA are available, they are not applied to their full extent [44]. To force a change, the Climate-smart Agriculture Booster or CSA Booster, was launched in the EU by climate Kic (http://csabooster.climate-kic.org/). The CSA Booster is Europe's leading innovation hub, community and collaboration platform pioneering the transition to climate-smart agriculture across Europe. By developing a multi-stakeholder network of public and private sector partners including research institutions, corporates, start-ups and international organisations the CSA Booster aims to incubate and catalyse the application, adoption and scaling of innovative and sustainable CSA solutions across Europe and beyond; and to accelerate and de-risk investments into CSA. The CSA Booster has developed an approach in which Climate Smart Solutions with technology innovations in soil resilience and carbon sequestration, precision and digital agriculture, and sustainable water and land use practices are scaled by providing support to overcome the main barriers for adoption of innovative technologies. By developing an open innovation platform, the CSA Booster enables collaboration, co-creation and matchmaking between stakeholders on supply and demand sides; the CSA Solution Finder (http://www.csaspatialsolutionfinder.org/), provides an opportunity to find CSA Solutions that work for a specific type of farming in a specific region in Europe (currently based on a profile of current greenhouse gas emission from dairy farming in EU), and the regional HUBs that are set up in France, Italy, Norway and The Netherlands, which serve as the local organisation to provide CSA Booster services, like CSA impact assessment on solutions, GHG emission reduction at farm level, CSA business models and agri-finance and insurance advice to local stakeholders.

The success of this example, though still under development, lies in the fact that the CSA-Booster has laid the foundation under a fundamental transition towards a Climate Smart agricultural sector by bringing together all relevant stakeholders, at a range of scales, realising that driving forces for change often occur at the higher end of the agricultural value chain, but that climate smart solutions should still provide an economic interesting perspective at the start of the value chain. Hence starting with SDGs 13 (Climate Change) and 12 (sustainable production), operating through SDG 8 (decent work 
and economic growth) eventually results in a great impact at SDG 15; with improved land management practices and the restoration of carbon-rich agricultural soils.

\section{Transition Management as a Tool to Evaluate the Current State of the Transition Towards a Sustainable Managed Soil Water System in the Netherlands}

The long-term vision for achieving the SDGs is a balance in the economic, societal and biological sphere and is based on a sustainably managed soil. Having shown for several Dutch cases that soil management strategies starting with the ambition to contribute to one SDG leads to benefits for multiple SDGs, it makes sense to introduce a tool that helps to evaluate the current state of the transition towards a sustainably managed soil water system in The Netherlands. We do this by making use of the transition theories of Loorbach et al. [45] and Loorbach and Oxenaar [13]. This evaluation intents to provide "transition glasses" to assess the societal challenges and make suggestions for transition-oriented, often more radical, interventions, it is not a thorough assessment of the current state. Loorbach et al., [45] have sketched an image on transitions as a process of construction and breakdown, during which after a long predevelopment phase (decades) the real transition phase is relatively short (years), chaotic and disruptive. The underlying patterns and dynamics are contained in their so-called X-curve, in which the state of transition can be mapped. Mapping transition dynamics means looking at signs of (1) experimentation, (2) acceleration (3) emergence, (4) institutionalization, and (5) stabilization, as well as at signs of (6) regime optimization, (7) emergence of corrective barriers, reducing (8) dependencies and (9) relevance resulting in phasing out of (innovative) soil management approaches (Figure 7). All phases can take place at the same time and different stakeholders can act and contribute to different phases at the same time. A rough assessment of the state of transition for agricultural soil management in The Netherlands is visualized in Figure 7 and is further explained in Table 1 on the basis of concrete examples.

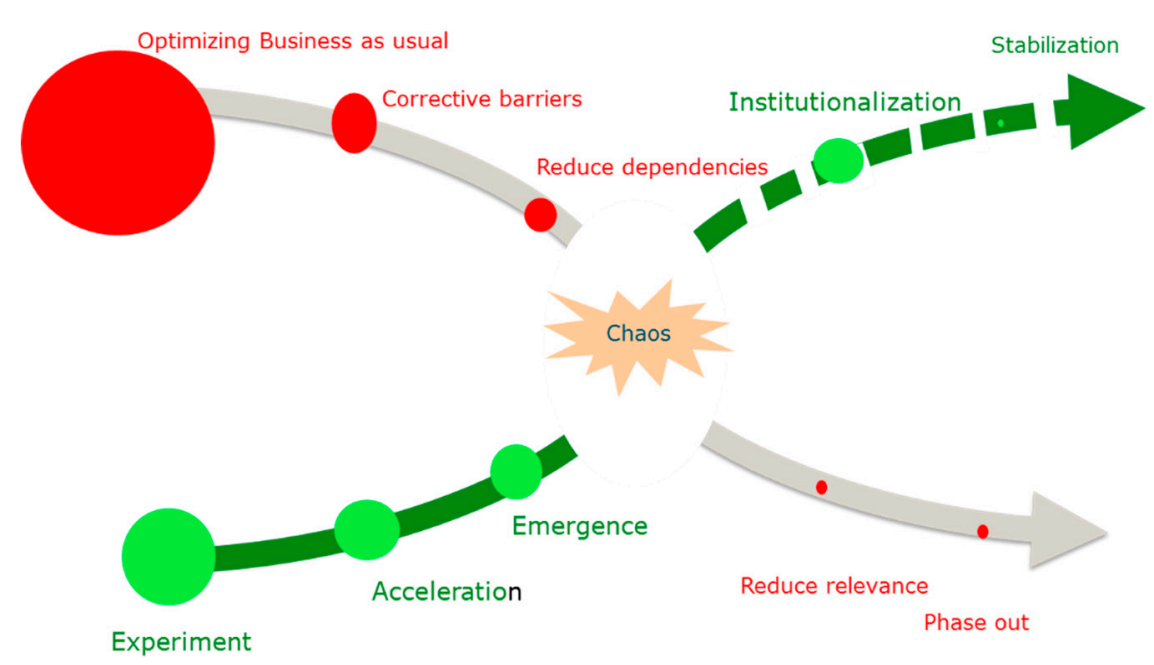

Figure 7. State of transition towards a sustainably soil management as a basis (in agriculture) to support realization of the SDGs in the Netherlands.

The size of the circles provides the relative state of the phase of transition based on the expert opinion of the authors, supported with examples in Table 1. The arrows indicate the direction for the transition, where the green arrow describes the path of the emergence of sustainable soil management as a basis and the grey arrow shows the path for breakdown of exiting practices (After [45].).

Starting from either of the three perspectives (society, economy and biosphere) the examples in the previous section can be considered an experiment in transition science for the agricultural sector and for the role of soil in that specifically the X-curve and the examples in Table 1 show that currently The Netherlands is in the midst of a transition regarding agricultural soil management. Stakeholders are seeking to understand the boundary conditions for a new sustainable system. Each stakeholder can 
assess in which part of the transition X-curve they are active. The realization of where they are, gives guidance to the next steps each stakeholder can take or demand from connected stakeholders. With the launch of the 10-step approach towards a circular agriculture by the Dutch minister of Agriculture, Nature and Food quality [46] which was supported by the soil strategy [47], the Dutch government has provided some of the boundary conditions to facilitate the transition.

Table 1. Examples underpinning the state of transition to a sustainably managed Soil and Water System in the Netherlands, focusing of agricultural soils (adjusted from [45]).

\begin{tabular}{|c|c|}
\hline Build-up of emerging practices with positive Soil ('bottom up') & $\begin{array}{l}\text { Phasing-out practices with negative Soil impacts ('top down' } \\
\text { and 'bottom up') }\end{array}$ \\
\hline Experimentation & Optimizing business as usual \\
\hline $\begin{array}{l}\text { Radically new ways of doing } \\
\text { Radically new ways of thinking } \\
\text { Example: } \\
\text { True cost accounting of food. A method developed by Eosta et al., } \\
\text { (2017) introducing the costs of soil erosion in the food price. } \\
\text { Organisation of the Innovating Soil } 3.0 \text { challenge by investment } \\
\text { fund Global FootShot; stimulating a radical change in soil research } \\
\text { and management. (http://www.foodshot.org/challenge.html) }\end{array}$ & $\begin{array}{l}\text { Improving the existing } \\
\text { "no doubt, we're on the right track" } \\
\text { Example: } \\
\text { Maximizing agricultural production strategies, "more crops } \\
\text { per drop", by assuming that we can maximize the agricultural } \\
\text { production function of soils without taking into account } \\
\text { additional soil functions. The Netherlands is known for its } \\
\text { high intensive agriculture. }\end{array}$ \\
\hline Acceleration & Corrective barriers \\
\hline $\begin{array}{c}\text { Alternatives are connecting } \\
\text { Alternatives become visible and accessible } \\
\text { Example:2015; FAO declared International Year of Soils; followed } \\
\text { by international adoption of C 4/1000 initiative to reach Paris } \\
\text { agreement. } \\
\text { In the Netherlands many new soil health initiatives are started; e.g., } \\
\text { Circulair Terrain Management), Soil Heros (https://soilheroes.com) } \\
\text { and Common land introducing a business approach to sustainable } \\
\text { Land Management (https://www.commonland.com) }\end{array}$ & $\begin{array}{l}\text { Incidents are fueling a feeling of urgency } \\
\text { Start of a fundamental discussion about the future/direction } \\
\text { Example: } 2018 \text { Public debate started by prof. H. Siepel in the } \\
\text { Netherlands on Zombie Soils and lack of attention for soil } \\
\text { Biology. } \\
\text { Announcement of minister of agriculture that by } 2030 \text { al Dutch } \\
\text { agricultural soils should be managed with minimal use of } \\
\text { fossil based fertilizers and no pesticides }\end{array}$ \\
\hline Emergence & Reduce dependencies \\
\hline $\begin{array}{l}\text { New structures become visible } \\
\text { Transition no longer controversial } \\
\text { Example: } \\
\text { In } 2018 \text { the Netherlands launched the Soil strategy by Schouten } \\
\text { (http://edepot.wur.nl/450865), with the ambition to have all Dutch } \\
\text { agricultural soils under sustainable management in } 2030 . \\
\text { The province of South Holland launched 3 "green circle" } \\
\text { initiatives, in which large concerns Farm Frites, Sulker Unie and } \\
\text { "de Graafstroom" lead a consortium of stakeholders towards a } \\
\text { joint sustainable future. In each of these initiative the soils } \\
\text { provides the basis for the sustainable green future dreams. } \\
\text { (https://www.groenecirkels.nl/nl/groenecirkels.htm) }\end{array}$ & $\begin{array}{l}\text { Contradictions and uncertainties } \\
\text { Conflicting interests and new relations } \\
\text { Example: } \\
\text { Farmers are uncertain in their decisions for change, this can } \\
\text { result in in-action in case the pressure for change is not large } \\
\text { enough. So far we have no examples in the Netherlands only } \\
\text { related to soil. }\end{array}$ \\
\hline Institutionalization & Reduce relevance \\
\hline $\begin{array}{l}\text { Detailing the new system } \\
\text { Optimization of the new system: } \\
\text { Example: } \\
\text { Elsen et al. (2019) Defining parameters that indicate what is to be } \\
\text { considered a sustainably managed Soil. This report is formally } \\
\text { approved by the politics. } \\
\text { Common Agricultural Policy stimulating and subsidizing GAEC }\end{array}$ & $\begin{array}{l}\text { Pushing away, letting go, and fall out of existing order } \\
\text { The losers of the transition become visible } \\
\text { Description: } \\
\text { Parties that did not manage to adopt soil health into their } \\
\text { business practices are being pushed out: their market share is } \\
\text { going down, their supply chains are being disrupted, and they } \\
\text { face regulatory and tax burdens. Their business models no } \\
\text { longer function within the new structures. So far we have no } \\
\text { examples in the Netherlands only related to soil. }\end{array}$ \\
\hline Stabilization & Phase-out \\
\hline $\begin{array}{l}\text { Detailing the new system } \\
\text { Optimization of the new system } \\
\text { Description: } \\
\text { Sustainable soil management has become the norm, optimization } \\
\text { now occurs in the form of further enhancing positive effects (e.g., } \\
\text { reaching land degradation rehabilitation). So far we have no } \\
\text { examples in the Netherlands only related to soil }\end{array}$ & $\begin{array}{l}\text { Letting go } \\
\text { Dealing with the loss } \\
\text { Description: } \\
\text { Companies with net negative impacts on Soil Health go } \\
\text { bankrupt or have to cease operations. Also for this stage we } \\
\text { have no examples yet. }\end{array}$ \\
\hline
\end{tabular}

\section{Next Steps to Facilitate the Transition}

Now that we have made a rough assessment of the state of transition in The Netherlands, we will discuss the transition in governance in relation to the role of knowledge management. To facilitate the transition in governance new ways of thinking and acting are introduced, taking into account the 
role of partners and stakeholders and the importance of shared agendas. Traditionally land and water policy focussed on the protection of the natural functions of the soil-water system. For water, EU legislation is in place e.g., the Water Framework Directive. However, there is no sectoral soil framework directive, although soil is addressed in a lot of directives and guidelines. More overarching, 'Land' can be seen as the spatial system for soil and water as an interacting system and is one of the most relevant corner stones of the 'biosphere' as described in Figure 1 that depict the Sustainable Development Goals (SDGs). Without these cornerstones the whole system becomes unstable and the SGDs cannot be achieved. The Millenium Assessment Reports that were published in 2005 Desertification and Biodiversity were used to formulate the new goals within the UN conventions on these topics and the Millenium Development Goals and now the SDGs. However, integration between the UN conventions and the SDGs should be better aligned to make impact. In a recent publication of the IPCC on Land Degradation it was noted that land is a Critical Resource [48]. They state that land is under pressure from humans and climate change, but it is part of the solution. They refer with this to indicate that land may be a solution to the problem of climate change by sequestering carbon in soils. To achieve this sustainable land management is essential.

We suggest in this paper a new "way ahead" in which is based on two ideas: firstly, to use a holistic approach, in which sustainable land functions are the key to transform landscapes. Secondly, to move our land management from 'protect' to 'sustainable use and restoration' of natural systems and their services, in order to build robust economic systems. This gives value to the natural system, which creates chances to finance the management and restoration of the system. This holistic management viewpoint enables the selection of the most suitable land function related to a location in the landscape. Not all land functions have to be realized on all locations within a landscape, but the most suitable function(s) should be selected for each location using soil functions as a basis.

\subsection{Holistic Approaches for Sustainable Land Management to Transform Landscapes}

Currently many land degradation problems are solved by solutions based on technology that include hard, engineered structures like terraces, dikes and reservoirs. Solutions based on the forces and capacities of nature, the ecosystem services of soils, plants and the forms landscape itself, are not commonly present in the minds of decision makers and landscape planners. Nature-based solutions are in most cases more sustainable, not only from an environmental point of view, but also from an economical point of view as they serve more than one purpose and usually have a longer lifetime, and in some cases even enhance themselves over time [16,17]. For this approach to be successful it is necessary to understand the dynamics and components of the system. Both from an environmental as well as from a socio-economic point of view.

On a large-scale, we can look at the landscape as a whole. A healthy landscape is a landscape which has multiple functions and sustainably merges these functions. This approach is based on several principles:

1. The foundation of the landscape is based upon a healthy soil system that can provide the full set of ecosystem services that are needed to realize societal issues;

2. Landscape restoration is a long-term process. Typically, it will take 20 years to achieve a sustainable system, from both an environmental, economic and social point of view;

3. The design of a sustainable landscape is based on stakeholder involvement, scientific knowledge and site/system specific knowledge. The involvement of all local stakeholders is essential because they need to become aware of how these new landscape design approaches are beneficial for all;

4. Each landscape unit has multiple functions at the same time;

5. Not all elements of a landscape have to be able to fulfil all required functions. Landscapes should be designed such that the services that a landscape provides can be optimized requiring the lowest economic input without depleting the natural resources. 


\subsection{Transition in Governance to Go from Protect to Sustainably Use And Restore}

Using a sustainably managed soil and water system as a basis to achieve the SDGs, we need to take into account issues like the fact that land is a private means which is used for societal impact, and furthermore, there is an economic struggle how the pay the true price for sustainable soil management [49]. The approaches that have proven to be successful in implementing sustainable projects have in common that they all use state-of-the-art knowledge of the natural system (hence use the holistic approach with nature-based solutions), and coordinate, and co-create the project plan in collaboration with stakeholders, that they take into account the constraints of the system, both from a biophysical as well as from a socio-economic point of view (using the holistic approach on landscapes) [2,50,51] (Figure 1). The Climate Smart Agriculture programs [43] that integrate sustainable development with climate action may serve as an example for how the problem of land degradation neutrality can be integrated with robust economic growth.

To reach the SDGs by 2030 we need action. We need smart concerted action. Action that is considered affordable and seen as an opportunity instead of as a burden. Transitions can be achieved by searching for the right balance between sometimes initially seemingly impossible compatible stakes and stakeholders. Loorbach et al., [45] argues that stakeholders can facilitate the transition by actively steering towards the desired changes and perspectives. Figure 8 shows that going from experimentation to acceleration and emergence; experimental space and support for scaling and connection with (new) structures needs to be facilitated. In order to change the current standard, we can increase the urgency and express pressure for change, break down existing structures arriving in a phase of chaos, from which we can aim at reducing dependencies and relevance and phasing out.

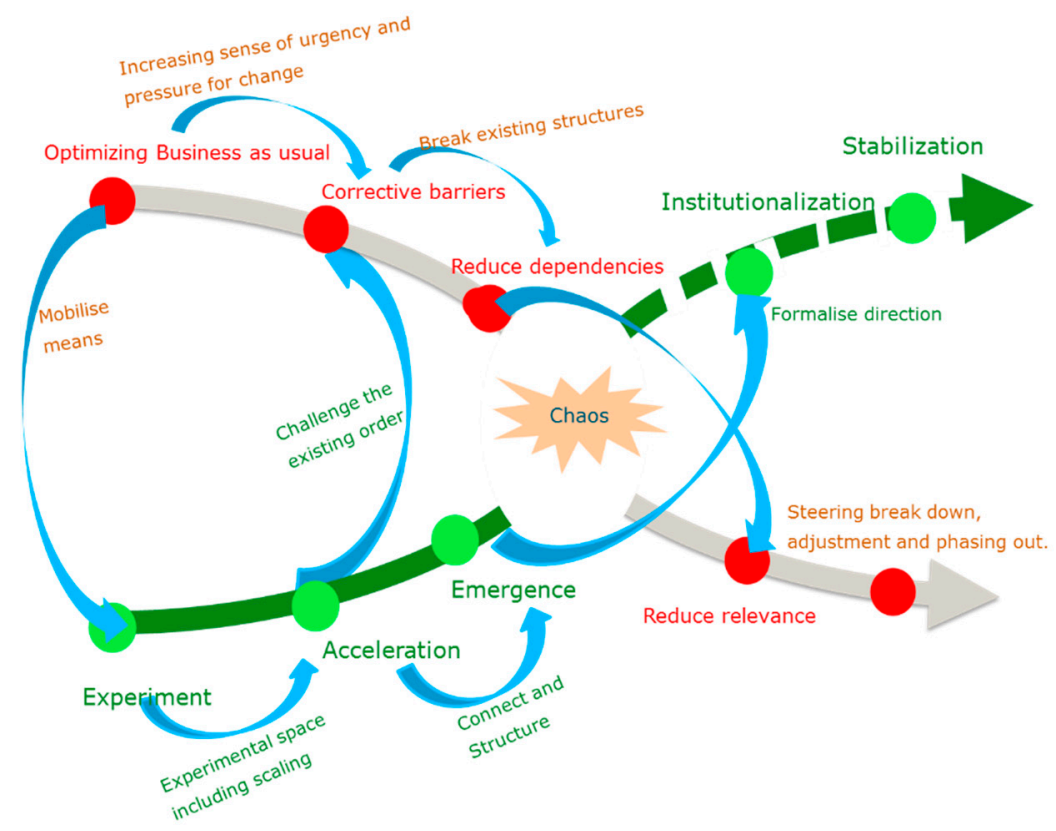

Figure 8. Scientist and policy action perspectives to facilitate the progress of transitions (after [46]). Green text refers to supportive action to realize the new desired state and red text refers to supportive actions the break down and phase out existing undesired structures.

For the transition towards a sustainable managed soil and water system, we should be aware that this transition is related to other transitions, such as the transition towards a circular agriculture in the Netherlands or Climate Action. This provides an opportunity for policy makers to look for frontrunners in their own organisation within all related sectors like climate, nature inclusive agriculture, water management in order to start a learning process. Like this, breakthroughs in existing structures appear and new integrated alternatives will arise, including interlinked research and development agenda's, challenging the existing structures (Figure 8). Such a break-through opens the route towards integrating 
existing instruments (mobilising financial resources) like subsidies and stimulation programs and include the boundary conditions to combine different SDGs, which extravagates the urgency and need to change. As the soil and water system is unique in each location, initiatives generally arise regionally, however strategies for sustainable management can often be adapted for a specific local situation. By stimulating knowledge exchange (connection) and collaboration the process of adoption of new technologies (scaling) can be significantly accelerated, which allows for a more orderly process of breaking down existing structures.

\section{Conclusions}

There is an increasing pressure on land, this calls for the use of land for different functions at the same time and for restoration of degraded land [52,53]. A sense of urgency is needed, because the deadline for the SDGS (2030) is like tomorrow for environmental issues. In this paper we combine two concepts: (1) The holistic approach to design location specific sustainable land management; and (2) transition science. Healthy soils and healthy land are the basic conditions to be able to achieve the goals described in the framework of the SDGs. Managing land in a sustainable way needs a holistic approach that takes into account both bio-physical and socio-economic aspects on a landscape scale with a long-term vision. For the successful implementation and realization of the SDGs each plan needs to be adapted for the specific situation it is aimed for. To do this we advocate that a transition approach is essential.

We may conclude that by making use of transition science and the X-curve for transition, soil and land stakeholders are given a framework, which provides an action perspective, specifically for science and governance stakeholders in each phase of the transition. With this framework, science and policy can (1) provide the required intensive guidance, whilst at the same time (2) analyze the impact of the provided incentives, (3) identify new reference points in the transition process, (4) identify transition catalysts, (5) innovate by testing cutting edge policy instruments in close cooperation with society. Depending on where in the transition actions take place, different kinds of knowledge and innovations are needed. Adopting a holistic approach for sustainable land management helps to develop knowledge for transformation of landscapes. In order to make sure the knowledge is used and applied properly, a framework for knowledge management like the roadmap from EJP SOIL targets for [35], can be jointly used with the framework for transition science. Such a knowledge management framework facilitates knowledge flow between diverse stakeholders in soil management and provides perspectives needed for actions. The take home message of this paper is to realize that all sustainability initiatives may contribute to the transition to a sustainable world. Scientists have an important role in (1) developing new knowledge and technologies and (2) analysing and monitoring the impact of knowledge, policy instruments and stakeholders on the transition process. Policy makers have an important role in (1) facilitation of knowledge exchange, (2) providing experimental space and (3) stimulating the speed of transition by providing the right financial and juridical instruments at the right moment in the transition.

Author Contributions: Conceptualization: S.V., S.K., C.M., M.d.C., Methodology: S.V., S.K., C.M., M.d.C., G.M., Investigation: S.V., S.K., C.M., M.d.C., G.M., Original Draft Preparation: S.V., S.K., C.M., M.d.C., G.M., Writing-review-editing: S.V., S.K., C.M., M.d.C., Visualization: S.V., S.K., Supervision: S.V., S.K.

Funding: Funding was provided by the ministery of Agriculture,, Nature and Food through the Knowledge base Program Circular and Climate Neutral; https://www.wur.nl/nl/Onderzoek-Resultaten/Onderzoekprogrammas/ Onderzoeks-en-investeringsprogrammas/Circulair-en-klimaatneutraal.htm.

Acknowledgments: The authors wish to thank nature for inspiring and refreshing us during long walks in the fields.

Conflicts of Interest: The authors declare no conflicts of interest. 


\section{References}

1. Müller, A.; Weigelt, J. Governance for a Land Degradation Neutral World; IISD Land Policy and Practice Knowledge Database; IISD: Winnipeg, MB, Canada, 2013.

2. Randers, J.; Rockström, J.; Stoknes, P.E.; Golüke, E.; Collste, D.; Cornell, S. Transformation is Feasible; How to Achieve the Sustainable Development Goals within Planetary Boundaries; A report to the Club of Rome, for its 50 years anniversary; Stockholm Resilience Centre: Stockholm, Sweden, 17 October 2018.

3. Report. p. 80. Available online: https://www.stockholmresilience.org/download/18.51d83659166367a9a16353/ 1539675518425/Report_Achieving\%20the\%20Sustainable\%20Development\%20Goals_WEB.pdf (accessed on 25 May 2019).

4. UNCCD. Article 2 of the Text of the United Nations Convention to Combat Desertification; UNCCD: New York, NY, USA, 1994.

5. Termeer, C.; De Wulf, A. Mogelijkheden van de 'Small Wins' Aanpak Voor de Transitie Opgaven van het Ministerie Van Infrastructuur En Waterstaat. Available online: https:/www.wur.nl/nl/nieuws/Rapport-smallwins-aanpak-voor-de-transitie-opgaven.htm (accessed on 20 August 2019).

6. Soussana, J.F.; Lutfalla, S.; Ehrhardt, F.; Rosenstock, T.; Lamanna, C.; Havlík, P.; Richards, M.; Chotte, J.L.; Torquebiau, E.; Ciais, P.; et al. Matching policy and science: Rationale for the ' 4 per 1000-soils for food security and climate'initiative. Soil Tillage Res. 2017, 188, 3-15. [CrossRef]

7. Smith, P.; House, J.I.; Bustamante, M.; Sobocká, J.; Harper, R.; Pan, G.; West, P.C.; Clark, J.M.; Adhya, T.; Rumpel, C.; et al. Global change pressures on soils from land use and management. Glob. Chang. Biol. 2016, 22, 1008-1028. [CrossRef]

8. Braat, L.C.; De Groot, R. The ecosystem services agenda: Bridging the worlds of natural science and economics, conservation and development, and public and private policy. Ecosyst. Serv. 2012, 1, 4-15. [CrossRef]

9. Doppelt, B. Leading Change Toward Sustainability: A Change-Management Guide for Business, Government and Civil Society; Routledge: London, UK, 2017.

10. Rotmans, J. Change of An Era; Our World in Transition; BOOM: Amsterdam, The Netherlands, 2017; p. 208.

11. Gorissen, L.; Vrancken, K.; Manshoven, S. Transition Thinking and Business Model Innovation. Towards a Transformative Business Model and New Role for the Re-use centers of Limburg, Belgium. Sustainability 2016, 8, 112. [CrossRef]

12. Sigurnjak, I.; Brienza, C.; Snauwaert, E.; De Dobbelaere, A.; De Mey, J.; Vaneeckhaute, C.; Michels, E.; Schoumans, O.; Adani, F.; Meers, E. Production and performance of bio-based mineral fertilizers from agricultural waste using ammonia (stripping-) scrubbing technology. Waste Manag. 2019, 89, 265-274. [CrossRef] [PubMed]

13. Loorbach, D.; Frantzeskaki, N.; Avelino, F. Sustainability transitions research: Transforming science and practice for societal change. Annu. Rev. Environ. Resour. 2017, 42, 599-626. [CrossRef]

14. Hajer, M. The energetic society. In Search of a Governance Philosophy for a Clean Economy; pbl Netherlands Environmental Assessment Agency: Hague, The Netherlands, 2014.

15. Schäpke, N.; Omann, I.; Wittmayer, J.M.; van Steenbergen, F.; Mock, M. Linking transitions to sustainability: A study of the societal effects of transition management. Sustainability 2017, 9, 737. [CrossRef]

16. Napoli, M.; Marta, A.D.; Zanchi, C.A.; Orlandini, S. Assessment of soil and nutrient losses by runoff under different soil management practices in an Italian hilly vineyard. Soil Tillage Res. 2017, 168, 71-80. [CrossRef]

17. Van Hattum, T.; Blauw, M.; Jensen, M.B.; de Bruin, K. Towards Water Smart Cites. Available online: http://edepot.wur.nl/407327 (accessed on 15 April 2019).

18. Keesstra, S.; Nunes, J.; Novara, A.; Finger, D.; Avelar, D.; Kalantari, Z.; Cerdà, A. The superior effect of nature based solutions in land management for enhancing ecosystem services. Sci. Total Environ. 2018, 610-611, 997-1009. [CrossRef]

19. Onat, N.C.; Kucukvar, M.; Halog, A.; Cloutier, S. Systems thinking for life cycle sustainability assessment: A review of recent developments, applications, and future perspectives. Sustainability 2017, 9, 706. [CrossRef]

20. Keesstra, S.D.; Bouma, J.; Wallinga, J.; Tittonell, P.; Smith, P.; Cerdà, A.; Montanarella, L.; Quinton, J.N.; Pachepsky, Y.; Van Der Putten, W.H.; et al. The significance of soils and soil science towards realization of the United Nations sustainable development goals. Soil 2016. [CrossRef] 
21. Schulte, R.; Creamer, R.E.; Donnellan, T.; Farrelly, N.; Fearly O’Donoghue, C.; O'hUallachain, D. Functional land management: A framework for managing soil-based ecosystem services for the sustainable intensification of agriculture. Environ. Sci. Policy 2014, 38, 45-58. [CrossRef]

22. Bünemann, E.K.; Bongiorno, G.; Bai, Z.; Creamer, R.E.; De Deyn, G.; de Goede, R.; Fleskens, L.; Geissen, V.; Kuyper, T.W.; Mäder, P.; et al. Soil quality-A critical review. Soil Biol. Biochem. 2018, 120, 105-125. [CrossRef]

23. Silva, A.; Stocker, L. What is a transition? Exploring visual and textual definitions among sustainability transition networks. Glob. Environ. Chang. 2018, 50, 60-74. [CrossRef]

24. Elsen, E.; Hanegraaf, M.; de Haan, J.; Visser, S.M. Systematiek voor bodemkwaliteitsbeoordeling van landbouwgronden in Nederland. Wageningen Res. Rep. 2019, 2944. Available online: http://edepot.wur.nl/ 475874 (accessed on 15 September 2019).

25. Keesstra, S.; Nunes, J.P.; Saco, P.; Parsons, T.; Poeppl, R.; Masselink, R.; Cerdà, A. The way forward: Can connectivity be useful to design better measuring and modelling schemes for water and sediment dynamics? Sci. Total Environ. 2018, 644, 1557-1572. [CrossRef]

26. Parsons, A.J.; Bracken, L.; Poeppl, R.E.; Wainwright, J.; Keesstra, S.D. Introduction to special issue on connectivity in water and sediment dynamics. Earth Surf. Process. Landf. 2015, 40, 1275-1277. [CrossRef]

27. Cerdà, A.; Rodrigo-Comino, J.; Giménez-Morera, A.; Keesstra, S.D. An economic, perception and biophysical approach to the use of oat straw as mulch in Mediterranean rainfed agriculture land. Ecol. Eng. 2017, 108, 162-171. [CrossRef]

28. Cerdà, A.; Rodrigo-Comino, J.; Giménez-Morera, A.; Keesstra, S.D. Hydrological and erosional impact and farmer's perception on catch crops and weeds in citrus organic farming in Canyoles river watershed, Eastern Spain. Agric. Ecosyst. Environ. 2018, 258, 49-58. [CrossRef]

29. Morel, J.L.; Chenu, C.; Lorenz, K. Ecosystem services provided by soils of urban, industrial, traffic, mining, and military areas (SUITMAs). J. Soils Sediments 2015, 15, 1659-1666. [CrossRef]

30. Artmann, M. Assessment of soil sealing management responses, strategies, and targets toward ecologically sustainable urban land use management. AMBIO 2014, 43, 530-541. [CrossRef] [PubMed]

31. Davis, M.; Naumann, S. Making the Case for Sustainable Urban Drainage Systems as a Nature-Based Solution to Urban Flooding. In Nature-Based Solutions to Climate Change Adaptation in Urban Areas; Springer: Cham, Switzerland, 2017; pp. 123-137.

32. Keesstra, S.D.; Mol, G.; De Leeuw, J.; Okx, J.; Molenaar, C.; De Cleen, M.; Visser, S.M. Soil-Related Sustainable Development Goals: Four Concepts to Make Land Degradation Neutrality and Restoration Work. Land 2018, 7, 133. [CrossRef]

33. SWD. Report from the Commission to the European Parliament, the Council, the European Economic and Social Committee and the Committee of the Regions on the Implementation of the Circular Economy Action Plan. Available online: https://eur-lex.europa.eu/legal-content/EN/TXT/PDF/?uri=CELEX:52019DC0190\& from $=\mathrm{EN}$ (accessed on 3 July 2019).

34. Long, T.; Blok, V.; Coninx, I. The diffusion of Climate-smart agricultural innovations: Systems level factors that inhibit sustainable entrepreneurial action. J. Clean. Prod. 2019, 232, 993-1004. [CrossRef]

35. Dalkir, K. The knowledge management cycle. In Knowledge Management in Theory and Practice; Elsevier: Oxford, UK, 2005; pp. 25-46.

36. Keesstra, S.D.; Visser, S.M.; NiChoncubhair, O.; Mulder, V.L.; Constantini, E.; Priori, S.; Sousanna, J.F.; Kuikman, P.; Olesen, J.; Barron, J.; et al. Roadmap for the European Joint Program SOIL: Towards Climate-Smart Sustainable Management of Agricultural. Published online on 23 January 2019. Available online: http://dca.au.dk/fileadmin/user_upload/EJP_SOIL_roadmap_final-23-01.pdf (accessed on 28 November 2019).

37. Rojas, R.V.; Achouri, M.; Maroulis, J.; Caon, L. Healthy soils: A prerequisite for sustainable food security. Environ. Earth Sci. 2016, 75, 180. [CrossRef]

38. Ferreira, C.S.S.; Keizer, J.J.; Santos, L.M.B.; Serpa, D.; Silva, V.; Cerqueira, M.; Ferreira, A.J.D.; Abrantes, N. Runoff, sediment and nutrient exports from a Mediterranean vineyard under integrated production: An experiment at plot scale. Agric. Ecosyst. Environ. 2018, 256, 184-193. [CrossRef]

39. Di Prima, S.; Lassabatere, L.; Rodrigo-Comino, J.; Marrosu, R.; Pulido, M.; Angulo-Jaramillo, R.; úbeda, X.; Keesstra, S.; Cerdà, A.; Pirastru, M. Comparing transient and steady-state analysis of single-ring infiltrometer data for an abandoned field affected by fire in Eastern Spain. Water (Switzerland) 2018, 10, 514. [CrossRef] 
40. Morvan, X.; Verbeke, L.; Laratte, S.; Schneider, A.R. Impact of recent conversion to organic farming on physical properties and their consequences on runoff, erosion and crusting in a silty soil. Catena 2018, 165, 398-407. [CrossRef]

41. Hong, N.B.; Yabe, M. Improvement in irrigation water use efficiency: A strategy for climate change adaptation and sustainable development of Vietnamese tea production. Environ. Dev. Sustain. 2017, 19, 1247-1263. [CrossRef]

42. Schouten, C. Nationaal Programma Landbouwbodems; Kamerstuk. DGA-PAV/19035321; Ministerie van Landbouw, Natuur en Voedselkwaliteit: Groningen, The Netherlands, 25 April 2019.

43. Walmsley, A.; Cerdà, A. Soil macrofauna and organic matter in irrigated orchards under Mediterranean climate. Biol. Agric. Hortic. 2017, 33, 247-257. [CrossRef]

44. FAO. "Climate-Smart" Agriculture; Policies, Practices and Financing for Food Security, Adaptation and Mitigation. 2010. Available online: http://www.fao.org/docrep/013/i1881e/i1881e00.htm (accessed on 3 March 2019).

45. Long, T.B.; Blok, V.; Poldner, K. Business models for maximising the diffusion of technological innovations for climate-smart agriculture. Int. Food Agribus. Manag. Rev. 2017, 20, 5-23. [CrossRef]

46. Loorbach, D.; Oxenaar, S. Transitions to a Natural Capital Positive Economy by Creating an Enabling Environment for Natural Capital Approaches; Counting on Nature Report; Government of the Netherlands, 2018. Available online: https://www.government.nl/documents/reports/2018/02/09/government-dialogue-on-natural-capitalcounting-on-nature (accessed on 28 November 2019).

47. Scheffer, M. Critical Transitions in Nature and Society; Princeton University Press: Princeton, CO, USA, 2007.

48. Schouten, C. Bodemstrategie; Kamerstuk 30015. nr. 54; Ministerie van Landbouw, Natuur en Voedselkwaliteit: Groningen, The Netherlands, 23 May 2018.

49. UNCCD. Impulse Report-Climate Change and Desertification: Anticipating, Assessing and Adapting to Future Change in Drylands; United Nations Convention to Combat Desertification: Rome, Italy, 2015.

50. Eosta, Soil \& More, EY, Triodos Bank and Hivos, 2017. True Cost Accounting for Food, Farming \& Finance (TCA-FFF). Available online: https://www.eosta.com/nl/nieuws/true-cost-accounting-pilot-berekentverborgen-kosten-voedselproductie (accessed on 15 August 2019).

51. Gladwin, T.N.; Kennelly, J.J.; Krause, T.S. Shifting paradigms for sustainable development: Implications for management theory and research. Acad. Manag. Rev. 1995, 20, 874-907. [CrossRef]

52. Rockström, J.; Williams, J.; Daily, G.; Noble, A.; Matthews, N.; Gordon, L.; Wetterstrand, H.; DeClerck, F.; Shah, M.; Steduto, P.; et al. Sustainable intensification of agriculture for human prosperity and global sustainability. AMBIO 2017, 46, 4-17. [CrossRef] [PubMed]

53. Arneth, A.; Barbosa, H.; Benton, T.; Calvin, K.; Calvo, E.; Connors, S.; van Diemen, R. Special Report On Climate Change, Desertification, Land Degradation, Sustainable Land Management, Food Security, and Greenhouse Gas Fluxes In Terrestrial Ecosystems; IPCC: London, UK, 2019.

(C) 2019 by the authors. Licensee MDPI, Basel, Switzerland. This article is an open access article distributed under the terms and conditions of the Creative Commons Attribution (CC BY) license (http://creativecommons.org/licenses/by/4.0/). 